\title{
Sex- and Age-Related Changes in Connexin 43 Expression in Normal Rat Bladder
}

\author{
Sung Ho Song, Hyun Taek Joo, Hyeon Wook Cho, Ha Wook Hwang, Ki Ho Lee ${ }^{1}$, Dae Kyung Kim \\ Departments of Urology, and ${ }^{1}$ Biochemistry, Eulji University College of Medicine, Daejeon, Korea
}

Purpose: Gap junctions are intercellular channels to facilitate electrical and metabolic communication between adjacent cells. Connexin 43 is the most predominant type of connexin expressed on rat detrusor muscle cells. We investigated the connexin 43 expressions in various age groups of either sex in normal rats.

Methods: Eighty Sprague-Dawley rats were used for analysis. Each group was quantified by 8 rats at 1 week, 2 weeks, 1 month, 3 months, and 6 months of age in either sex. In each animal, bladder was removed without any kind of intervention and fresh-frozen in liquid nitrogen. Total RNA extraction was done with easy-BLUE total RNA extraction kit. Reverse transcription polymerase chain reaction was done for connexin 43 and glyceraldehyde-3-phosphate dehydrogenase as an internal control using ImProm-II Reverse Transcription System.

Results: In female rats, no age-related change was detected in connexin 43 expressions. In male rats, connexin expression at 3 months of age showed significant decrease compared with 1 week, 2 weeks, and 6 months of age $(P<0.05)$. When connexin expression at the same age in male and female were compared, only 3 months group in male showed significant decrease than the same age group in female.

Conclusions: Our data suggest that the expressions of connexin 43 mRNA in normal detrusor muscle cell showed age-related changes especially in male rats. Although it is difficult to interpret these findings at this stage, age should be considered as a possible compounding factor affecting connexin 43 expressions in male rats.

Keywords: Gap junction; Connexin; Bladder

\section{INTRODUCTION}

Gap junctions are intercellular channels that facilitate communication between the intracellular compartments of adjacent cells and the exchange of electrical signals. Connexin 43 is the predominant type of connexin expressed in rat bladder [1]. Many previous studies have reported that the expression of connexin 43 is increased in cases of overactive bladder or partial bladder outlet obstruction [2,3]. However, no sex- or agerelated changes in connexin 43 expression have yet been reported. We investigated connexin 43 expression in various age groups of normal rats of both sexes.

\section{MATERIALS AND METHODS}

Eighty Sprague-Dawley rats were used for analysis. A total of 8 rats in each group were studied at 1 week, 2 weeks, 1 month, 3 months, and 6 months of age in either sex. In each group, rats were euthanized by $\mathrm{CO}_{2}$, and a midline abdominal incision was made. The bladder was removed without any kind of intervention. Immediately after resection, the bladder specimens were fresh-frozen in liquid nitrogen and preserved at $-80^{\circ} \mathrm{C}$ until RNA extraction.

Total RNA extraction was done with the easy-BLUE total RNA extraction kit (Intron Biotechnology, Seongnam, Korea).
Corresponding author: Dae Kyung Kim

Department of Urology, Eulji University Hospital, Eulji University College of Medicine, 1306 Dunsan 2-dong, Seo-gu, Daejeon 302-799, Korea

Tel: +82-42-611-3529 / Fax: +82-42-611-3538 / E-mail: dkkim@eulji.ac.kr

Submitted: December 1, 2010 / Accepted after revision: March 20, 2011
This is an Open Access article distributed under the terms of the Creative Commons Attribution Non-Commercial License (http://creativecommons.org/licenses/by-nc/3.0/) which permits unrestricted non-commercial use, distribution, and reproduction in any medium, provided the original work is properly cited. 
A mixed solution of $1 \mu \mathrm{g}$ of extracted total RNA and $1 \mu \mathrm{L}$ oligo (dT) 15 primer and $3 \mu \mathrm{L}$ nuclease-free distilled water was incubated at $70^{\circ} \mathrm{C}$ for 5 minutes and thereafter stored on ice for 10 minutes. RNA purity was confirmed by using a ultraviolet spectrometer to check the absorbance ratio at $260 \mathrm{~nm} / 280 \mathrm{~nm}$.

cDNA was synthesized from extracted total RNA by use of the ImProm-II Reverse Transcription System (Promega, Madison, WI, USA). Twenty microliters of mixed solution with 3.8 $\mu \mathrm{L} 25 \mathrm{mM} \mathrm{MgCl}_{2}, 4 \mu \mathrm{L}$ reaction buffer, $1 \mu \mathrm{L}$ dNTP $(10 \mathrm{mM}$ mixture of dATP, dCTP, dGTP, and dTTP), $1 \mu \mathrm{L}$ RNase inhibitor, $1 \mu \mathrm{L}$ ImProm-II reverse transcriptase, and nuclease-free distilled water was incubated at $25^{\circ} \mathrm{C}$ for 5 minutes and thereafter at $42^{\circ} \mathrm{C}$ for 90 minutes. To inactivate reverse-transcriptase, the mixture was incubated at $70^{\circ} \mathrm{C}$ for 15 minutes and was then stored at $-20^{\circ} \mathrm{C}$.

The sense and antisense primer sequences for connexin 43 and an internal control gene, glyceraldehyde 3-phosphate dehydrogenase (GAPDH), are shown in Table 1. For connexin 43, 1 $\mu \mathrm{L}$ cDNA, $2.475 \mu \mathrm{L}$ of 10x PCR buffer (20 mM Tris- $\mathrm{HCl}, \mathrm{pH}$ 8.0, $100 \mathrm{mM} \mathrm{KCl}, 0.1 \mathrm{mM}$ ethylenediaminetetraacetic acid, 1 $\mathrm{mM}$ dithiothreitol, $50 \%$ glycerol, $0.5 \%$ Tween 20 , and $0.5 \%$ Nonidet-P40), $0.5 \mu \mathrm{L}$ dNTP (10 mM mixture of dATP, dCTP, dGTP, and dTTP), $10 \mathrm{pM}$ of each sense and antisense primer, $0.25 \mu \mathrm{L}$ Taq DNA polymerase (Promega), and nuclease-free distilled water was added to make $25 \mu \mathrm{L}$ of mixed fluid for polymerase chain reaction (PCR). PCR was done in a thermal cycler (GeneAmp PCR System 9700, Applied Biosystems, Foster City, CA, USA) with 5 minutes of preheating at $94^{\circ} \mathrm{C}$ and 35 repeated cycles of reactions at $94^{\circ} \mathrm{C}$ for 45 seconds, $52^{\circ} \mathrm{C}$ for $45 \mathrm{sec}$ onds, and $72^{\circ} \mathrm{C}$ for 45 seconds. A final incubation was done at $72^{\circ} \mathrm{C}$ for 10 minutes, and the reaction was stopped at $4^{\circ} \mathrm{C}$. For $G A P D H, 10$ pM of sense and antisense primers were mixed and PCR was carried out with 5 minutes of preheating at $94^{\circ} \mathrm{C}$ and 30 repeated cycles of reactions at $94^{\circ} \mathrm{C}$ for 30 seconds, $70^{\circ} \mathrm{C}$

Table 1. Primer sequences used for polymerase chain reaction

\begin{tabular}{llc}
\hline Primer & \multicolumn{1}{c}{ Sequence $5^{\prime} \rightarrow 3^{\prime}$} & Size $(\mathrm{bp})$ \\
\hline Connexin 43 & & 1,275 \\
Sense & TGGGGGAAAGGCGTGAG & \\
Antisense & CTGCTGGCTCTGCTGGAAGGT & \\
GAPDH & & 983 \\
Sense & TGAAGGTCGGTGTGAACGGATTTGGC & \\
Antisense & CATGTAGGCCATGAGGTCCACCAC & \\
\hline
\end{tabular}

$G A P D H$, glyceraldehyde 3-phosphate dehydrogenase. for 30 seconds, and $72^{\circ} \mathrm{C}$ for 60 seconds. The final incubation was done at $72^{\circ} \mathrm{C}$ for 10 minutes, and the reaction was stopped at $4^{\circ} \mathrm{C}$. Electrophoresis of $9 \mu \mathrm{L}$ of each PCR product and a 100bp ladder (Seegene Inc., Seoul, Korea) was done on agarose gels with ethidium bromide. The results of electrophoresis were saved by a digital camera connected to a computer, and the signal densities of the gels were analyzed by use of National Institutes of Health image software.

For statistical analysis, the SPSS ver. 11.5 (SPSS Inc., Chicago, IL, USA) was used. To compare age groups in each sex, the Kruskal-Wallis test and Tukey test were used. To compare sex groups at a specific age, the Wilcoxon signed-rank test was used.

\section{RESULTS}

In the quantitative analysis of connexin 43 expression by reverse transcription-PCR, the male 1-week group, 2-week group, and 6-month group showed significant increases in expression compared with the male 3 -month group ( $\mathrm{P}<0.05$, Fig.1). However, among female rats, no age-related changes in connexin 43 expression were found. When we compared connexin 43 expression in both sexes at the same age, no statistically significant differences were found at 1 week, 2 weeks, 1 month, or 6 months

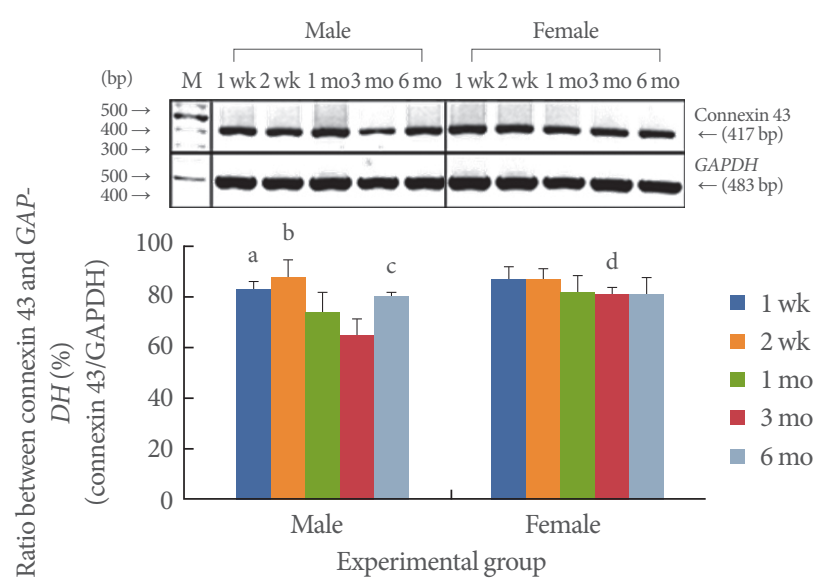

Fig. 1. Quantitative determination of the polymerase chain reaction (PCR) bands for connexin 43 in normal rats. With quantitative analysis of connexin 43 expression by reverse transcription-PCR, male 1 week-group (a), 2 week-group (b), 6 monthgroup (c) showed significant increase compared with male 3 month-group $(\mathrm{P}<0.05)$. Also, female 3 month-group (d) showed significant increase than male 3 month-group $(\mathrm{P}<0.05)$. M, marker; 1 wk, 1 week-group; 2 wk, 2 week-group; 1 mo, 1 month-group; 3 mo, 3 month-group; 6 mo, 6 month-group; $G A P D H$, glyceraldehyde 3-phosphate dehydrogenase. 
of age. In the 3-month age group, however, connexin 43 expression was significantly less in male rats than in female rats $(\mathrm{P}<0.05)$.

\section{DISCUSSION}

The myogenic theory is regarded as one of the pathophysiologic mechanisms that lead to overactive bladder syndrome. In the myogenic theory, changes in the intercellular gap junction, which is the pathway of electrical coupling between smooth muscle cells, have been widely investigated [4]. The gap junction is a special conjugation between the cell membranes of two cells. Gap junctions make a pathway with relatively reduced electrical resistance and create communication channels for various chemical substances. If an electrical signal is generated in one cell, the change is rapidly spread to nearby cells in a very short time. This type of electrical signal transmission has an advantage over neurons in the respect of signal transmission in that it does not require any kind of special neurotransmitters. Therefore, this type of rapid electrical signal transmission plays an important role in the function of smooth muscles, which require synchronized contraction. Gap junctions exist in cell membranes of smooth muscle in bladder and help to coordinate contraction and effective voiding [5]. However, if the gap junction is activated excessively, the electrical coupling of cells of bladder smooth muscle increases and uninhibited detrusor contractions can be generated with a lower threshold than the usual contraction. This phenomenon may present as symptoms such as urgency, which is the key symptom of overactive bladder syndrome [6].

Gap junction protein is expressed as uniform hexagonal particles of 6-8 nm called connexin. Among the many types of connexin, connexin 43 has been reported as a key structural protein of gap junctions in bladder smooth muscle [4]. Haefliger et al. [1] reported the mRNA expression of connexin 43 and connexin 26 in obstructed rat bladder. Christ et al. [7] demonstrated that the longer the time of bladder outlet obstruction, the greater the expression of connexin 43 in experimental rats. Also, in human bladder, the expression of connexin 43 in bladder from patients with overactive bladder was significantly increased compared with the expression in normal controls $[2,8]$.

Gap junctions show differences in expression pattern related to development in individuals, and it has been reported that this phenomenon exists in aortic endothelium [9], brain [10,11], cochlear cells [12], and heart [13]. It has also been reported that age- and gender-related changes in voiding function exist. Chun et al. [14] reported that sexually mature bladders show a greater sensitivity to bethanechol administration than do immature bladders. Szigeti et al. [15] reported that the spontaneous contractile activity of rat bladder had age-dependency; it was high in neonate bladder, low in adults, and reemerges in old ages. In experimental partial bladder outlet obstruction model with rat, the increased spontaneous activity of rat bladder is associated with the increased expression of connexin $43 \mathrm{mRNA}$ [7]. These findings may suggest that there are differences in the gap junctions of bladder smooth muscle according to age and gender. However, sex- or age-related changes in connexin expression have not previously been reported in bladder.

Our data suggest that the expression of connexin $43 \mathrm{mRNA}$ in normal detrusor muscle cells shows age-related changes, especially in male rats. Although it is difficult to interpret these findings at this stage, age may be considered as a possible confounding factor affecting connexin 43 expression in male rats.

\section{CONFLICT OF INTEREST}

No potential conflict of interest relevant to this article was reported.

\section{REFERENCES}

1. Haefliger JA, Tissières P, Tawadros T, Formenton A, Bény JL, Nicod P, et al. Connexins 43 and 26 are differentially increased after rat bladder outlet obstruction. Exp Cell Res 2002;274:216-25.

2. Haferkamp A, Mundhenk J, Bastian PJ, Reitz A, Dörsam J, Pannek J, et al. Increased expression of connexin 43 in the overactive neurogenic detrusor. Eur Urol 2004;46:799-805.

3. Mori K, Noguchi M, Matsuo M, Nomata K, Suematsu T, Kanetake H. Decreased cellular membrane expression of gap junctional protein, connexin 43 , in rat detrusor muscle with chronic partial bladder outlet obstruction. Urology 2005;65:1254-8.

4. Neuhaus J, Wolburg H, Hermsdorf T, Stolzenburg JU, Dorschner W. Detrusor smooth muscle cells of the guinea-pig are functionally coupled via gap junctions in situ and in cell culture. Cell Tissue Res 2002;309:301-11.

5. John H, Wang X, Wehrli E, Hauri D, Maake C. Evidence of gap junctions in the stable nonobstructed human bladder. J Urol 2003; 169:745-9.

6. Hashitani H, Fukuta H, Takano H, Klemm MF, Suzuki H. Origin and propagation of spontaneous excitation in smooth muscle of 
the guinea-pig urinary bladder. J Physiol 2001;530(Pt 2):273-86.

7. Christ GJ, Day NS, Day M, Zhao W, Persson K, Pandita RK, et al. Increased connexin43-mediated intercellular communication in a rat model of bladder overactivity in vivo. Am J Physiol Regul Integr Comp Physiol 2003;284:R1241-8.

8. Neuhaus J, Weimann A, Stolzenburg JU, Wolburg H, Horn LC, Dorschner W. Smooth muscle cells from human urinary bladder express connexin 43 in vivo and in vitro. World J Urol 2002;20:250-4.

9. Yeh HI, Chang HM, Lu WW, Lee YN, Ko YS, Severs NJ, et al. Agerelated alteration of gap junction distribution and connexin expression in rat aortic endothelium. J Histochem Cytochem 2000;48: 1377-89.

10. Prime G, Horn G, Sutor B. Time-related changes in connexin mRNA abundance in the rat neocortex during postnatal development. Brain Res Dev Brain Res 2000;119:111-25.
11. Solomon IC, Halat TJ, El-Maghrabi R, O’Neal MH 3rd. Differential expression of connexin 26 and connexin 32 in the pre-Bötzinger complex of neonatal and adult rat. J Comp Neurol 2001;440:12-9.

12. Ichimiya I, Suzuki M, Mogi G. Age-related changes in the murine cochlear lateral wall. Hear Res 2000;139:116-22.

13. Fromaget C, el Aoumari A, Gros D. Distribution pattern of connexin 43, a gap junctional protein, during the differentiation of mouse heart myocytes. Differentiation 1992;51:9-20.

14. Chun AL, Wein AJ, Harkaway R, Levin RM. Comparison of urinary bladder function in sexually mature and immature male and female rats. J Urol 1990;143:1267-71.

15. Szigeti GP, Somogyi GT, Csernoch L, Széll EA. Age-dependence of the spontaneous activity of the rat urinary bladder. J Muscle Res Cell Motil 2005;26:23-9. 